\title{
COGNITIVE PSYCHOLOGY OF ISLAMIC PERSPECTIVE
}

\author{
(Critique of Modern Psychology Studies)
}

\author{
Evita Yuliatul Wahidah ${ }^{1}$ \\ Moh. Toriqul Chaer ${ }^{2}$ \\ Agus Salim ${ }^{3}$ \\ Achmad Rozi ${ }^{4}$ \\ Sudrajat 5
Evitayuliatulwahidah.21@gmail.com, toriqul210874@gmail.com, agus.salim@ulm.ac.id, enggus.eroy@gmail.com

\begin{abstract}
Cognitive psychology is a psychological process that involves human knowledge. Islam has a unique view of humans from the cognitive realm, which contains God's instructions about the creation of humans. The study of human nature expressed or implied and offers problem-solving for the problems of human life. This research is a qualitative study. Data was collected through the literature review of Cognitive Psychology from an Islamic perspective. The research was conduct by collecting document studies from different research results, observations and interviews. Cognitive psychology in Islam does not only focus on the brain because the thought process also includes feelings, passions, and conscience. The study of cognitive psychology from an Islamic perspective presents the method of Islamization of knowledge and an effort to explore aspects of cognitive psychology in Islam. The Islamic perspective of cognitive psychology provides an alternative to the criticism of modern psychology, which breaks away from religious values.
\end{abstract}

Keywords: Cognitive Psychology, Perspective, Islamic

Abstrak: Psikologi kognitif merupakan proses psikologis yang melibatkan pengetahuan manusia. Islam memiliki pandangan yang khas mengenai manusia dari ranah kognitifnya, yang memuat petunjuk Tuhan tentang penciptaan manusia. Kajian hakekat manusia yang tersurat maupun tersirat dan menawarkan problem solving problematika kehidupan manusia. Kajian ini merupakan studi kualitatif. Data dikumpulkan melalui literatur kajian Psikologi Kognitif dalam perspektif Islam. Riset dilakukan dengan teknik pengumpulan studi dokumen dari berbagai hasil riset, observasi dan wawancara. Psikologi kognitif dalam Islam tidak hanya memusatkan pada otak, tapi juga proses

\footnotetext{
1 STIT Muhammadiyah Bojonegoro

2 STAI Masjid Syuhada Yogyakarta

3 Universitas Lambung Mangkurat

4 Universitas Primagraha Serang, Banten

${ }^{5}$ Universitas Muhammadiyah Cirebon
}

134 Volume 12 Nomor 2 October 2021

Submitted: 08-08-2021 Accepted: 09-09-2021 Approved: 11-09-2021 Published: 15-10-2021 
berpikir yang meliputi perasaan, nafsu, dan hati nurani. Kajian Psikologi Kognitif perspektif Islam menghadirkan metode Islamisasi ilmu, dan upaya menggali aspek psikologi kognitif dalam perspektif Islam. Psikologi Kognitif perspektif Islam memberikan ruang alternatif atas kritik psikologi modern yang melepaskan diri dari nilai-nilai ketuhanan.

Kata kunci: Psikologi Kognitif, Perspektif, Islam

\section{Introduction}

Postmodernism that arose at the end of 20 century arisen Deconstruction Spirit (mind discharging) in the establishment which assumes that the West World was (Wani 2011); (Wang 2007); (Herrington 2013). The right of life of various cultures existence also admitted and appreciated. At the beginning of the 15th Hijriyah century, Muslims started to appear the spirit of Islamic Resurrection.

Critics in modern science assumed producing dilemmatic polemic since science epistemology is too rationalistic. Over rationalistic science makes humans far from the values of religion. As stated by Fritjof Capra in "The Turning Point: Science, Society, and The Rising Culture", that modern science has apart from the values of religion. The arising of the critic in modern science is not only in the western world but also in the Islamic world (Sternberg, 2017). Science Islamization is one of the movements that put forward action after the proclamation of Islamic resurrection in the 15th Hijriyah century in the 1970s.

With the foundation of the Quran, Islam offers an alternative solution in encountering science growth, including Cognitive Psychology. Islam is the religion that is sent to humans as Rahmatan li Âl'amîn (bless for the universe). Its doctrines always spread kindness for human life in the world. It is as Allah Swt states (QS Toha: 2), which means "We have not sent down to you the Qur'an that you be distressed". It means that the human being willing to follow the guidance of the Al Quran will be a guaranty by Allah in understanding science. Islam is coring on three principles, Iman (belief), Islam (surrender), Ihsan (doing kindness). This core grows a set of beliefs, rituals, and complex behaviour etic systems but flexible in practice. Hence, there is sufficient room for adoption, adaptation, and accommodation process, the genius in the specific border.

Cognitive psychology is part of human psychology which is essential to learn. Cognitive psychology is often called intellectual psychology or intelligence ( $\mathrm{Lu}$ and Dosher 2007). Human cognitive psychology involves gaining knowledge, arranging, and using knowledge and other activities such as thinking, remembering, understanding, considering, observing, analyzing, synthesizing, evaluating, and breaking problems through interaction with the environment. 
Human brightness (intelligence) grows in line with an interaction between one progress to another, between one individual to another, and its nature. That is why an individual can learn and increase his essential intelligence potential. Discussing cognitive development means discussing individual development in thinking or cognitive processing or identification processing.

However, Islam also gives meaning to the human cognitive development concept. Explanation from Qur'an and hadith also the statement from ulama about the development of human cognition. In this paper, the writer will discuss human cognitive psychology observed from the Islamic perspective.

\section{Research methods}

This type of research is qualitative research. The data to be collected in this study is data that follows the research focus. The data sources in this study were taken from non-human data sources in the form of documents relevant to the research focus, such as literature books, references, or writings related to the research focus.

The data collection procedure used in this qualitative research is document review. In the Data Analysis Method, Miles and Huberman argue that data analysis in qualitative research consists of three streams of activities that coincide, namely data reduction, data presentation, conclusion drawing, or verification (Matthew, 1992)

In qualitative research, data checking is one of the essential activities. The implementation of checking the validity of the data, according to Moleong, is based on four criteria, namely: the degree of trustworthiness (credibility), transferability, dependability, and certainty (confirmability) (Moleong 2011). In this case, it can be explained as follows: first, credibility (credibility). To obtain valid data, the researchers used data checking techniques through (1) continuous observation, (2) triangulation of data sources, methods, and other researchers; (3) member checking (member check), peer-reviewing; and (4) checking the adequacy of references (referential adequacy checks), as stated by (Emzir 2010).

Second, Transferability in qualitative research can be achieved because of the similarity between the context of the information provider and the recipient. To carry out this transfer, the researcher provides sufficient descriptive data to conclude (Moleong 2011). The findings obtained are not part of the detailed description that the researcher has compiled, but the interpretation of the data described in detail with a sense of responsibility and based on natural conditions in the field (Sutton and Austin 2015); (Bengtsson 2016)

Third, Dependability. Dependability or dependence is carried out to avoid errors in conceptualizing research plans, collecting data, interpreting findings, and 
reporting research results carried out by researchers (Moleong 2011). To avoid errors in the study, the researcher considers examining the data by paying attention to other factors that are related in the context of examining the data.

Fourth, Confirmability. Confirmability or certainty is needed to determine whether the data obtained are objective or not (Emzir 2010). Certainty on the validity of the data obtained objectively depends on the agreement of several people to the views, opinions, and findings of a person. If the data has been agreed upon by several or many people, it can be objective, but the emphasis remains on the data (Pontoh 2016).

\section{Results and Discussion}

\section{A. The Study about Cognition as Part of Psychology Research}

\section{The Definition of Cognition}

Cognitive concept (in Latin cognoscente, "to find out" or "to identified") refers to the ability in processing information, practising science, and changing trends (Nehlig, 2010). Cognition also refers to a scope of high level in brain function, including the ability in learning and remembering; setting the plan and solving a problem; focusing, maintaining and distracting attention necessarily; understanding and using language; figuring out surrounding accurately, and conducting calculation (National Multiple Sclerosis Society, 2019).

According to Sternberg, cognitive is mental faculty related to knowledge, covering perception, reasoning, knowing, understanding, assessing, and imaging. Ignition is a complex concept involving at least aspects of memory, attention, executive function, perception, language, and psychomotor function ( $\mathrm{Lu}$ and Dosher, 2007); (Sternberg, 2017). Even all aspects in this matter are complex. Though, a memory covering the process of encoding, information saving and taking can also be divided into short term, long term, and working memory.

Attention can be selectively focused, divided or continued, and the perception includes some process levels to identify the object gaining from different sense stimuli (visual, auditory, touch, smell). Executive function involves reasoning, planning, evaluating, thinking strategy. On the other hand, the language cognitive aspect relates to verbal expression, word vocabulary, fluency, and understanding. A psychomotor function relates to programming and motoric execution. Furthermore, all cognitive functions are affected by a heart condition (sad or happy), alertness level and power, physical wealth, and motivation (Tyng et al., 2017).

Definitively, cognition is very hard to interpret since this concept is used widely in some contexts (neurocognitive, cognitive science, cognitive psychology) that give 
some specific definitions but none that general. That is why, cognitive function can conclude as all mental process which uses by an organism to control information, like getting input from the surrounding (perception), choosing (attention), representing (comprehension) and saving (memory) information and at the end using this knowledge to guide behaviour (motoric output reasoning and coordinating) (Bostrom and Sandberg 2009)

\section{History of Cognitive}

Cognition is understanding as a mental process because cognition reflects thought and cannot observe directly. Because of this reason, cognition cannot be measured directly, instead of through shown and able to observe behaviour. For example, children can remember numbers from 1-100, answer questions and assess correct and incorrect behaviour suitable to imitate.

For the further finding of cognition, then rises cognitive psychology which learning about the human thinking process. The thinking process involves the brain and its nerves as a human thinking device. That is why learning about brain function in thinking raises cognitive neuroscience. The experiment results related to both sciences are used a lot by robotic science I developing artificial intelligence.

This processing capability is limit by the factor of working memory capacity and time. The act includes cognitive and physical processes with human body parts (finger, hand, leg, and voice). The act can also be a passive act, which means continuing a work conducted before.

Factors that influence difficulty and speed in response choosing and conducting are decision complexity, reflecting in response, trading off in speed and accuracy, and feedback. Decision complexity is influence by the number of acts that probably chose, which also affects the time length of decision making. The response thinking influence by accepted information. If the accepted information predicted before, the information process would have been faster than the unpredicted information. A trade-off between speed and accuracy is a negative correlation between both of them, choosing and practising. In some situations, the faster someone in choosing a response, the mistake possibility that happens increases. Feedback is an effect that someone identifies as a verification for the conducted act. The time range between act and feedback should minimize.

\section{B. Cognitive Psychology in Islamic Approach}

Cognitive psychology often calls for intellectual psychology or intelligence. Individual brightness (Intelligence) increases in line with interaction between one development aspect with others and between one individual with others, and so does its nature. Cognitive psychology, cognitive approach, and cognitivist approaches 
identify with the thinking process, either mentally or intellectually. It gives contribution in educational word. Specifically, cognitive psychology is a study field about how a human understands, learns, remembers, and thinks about a piece of information (Facebook and Twitter 2019). Piaget, Gestalt, Vygotsky, Gagne, Bruner, and Ausubel pioneer figures who pioneer cognitive psychology.

Piaget appears with the cognitive development process, which explains some cognitive stages ('Piaget Stages of Development: What Are They and How Are They Used?' 2018). Max Wertheimer pioneered Gestalt Theory (1880 - 1943), studying observation and problem-solving. That observation gives regret on the using of memorizing method at school. It requires that the students learn with meaning, not academic memorizing.

Vygotsky stressed how mental development processes, such as memory, attention, and reasoning, involve learning that uses society discovery. Vygotsky, who is admiring Piaget, stresses culture role and society in cognitive development, different from Piaget's description of child as a lonely little scientist. Piaget looks at children as learning through individual discovery. At the same time, Vygotsky is more stressing about adult roles and other children. Moreover, there are still many more discussions about cognitive psychology from the pioneer of cognitive psychology that are known widely in the psychology field. Cognitive psychology is often called intellectual psychology or intelligence.

Words that have meaning intelligence or brightness are Fathanah (bright), dzaka (genius), hadzaqah (expert), nubl (bright)najabah (brilliant), and kayyis (clever). A clear definition of intelligence is not found, but through the words stated by Qur'an can be concluded the meaning of intelligence. The word that Al Quran often uses is the word with close meaning with intelligence, such as the word that related al- "aql, al-lubb, al-fikr, al-Bashar, al-Nuha al-figh, al-fikr, al-Mazhar, al-tadabbur, dan al-dzikr. Those are often used in Al Quran in the form of verb, like the word ta'qilun. Some interpretation experts, Muhammad Ali Al-Shabuni, interprets the word afala ta' qilun, "Don't you use your mind?"

The use of mind or intelligence measures intelligence in Al Quran dedicated for positive way, both for one to another. The appearance of cognitive psychology cannot avoid by other critics. Cognitive psychology concludes that every job and act begins from an internal mind (whisper - imagination - feel - emotion). Then, their knowledge stopped here. In reality, revelation complete the current information by expressing the early source before human cognitive potency begins to work and produce a conation potency (Stangor, 2014); (Greenfield and Ribbins, 2015). Conation is a will, wish or desire from an individual. Will, wish, want and desire to reach and to gain something. 
The followers of a cognitive theory are called humans as homo sapiens (thinking human). According to this group, a human does not see as a creature reacts to the environment passively and always thinks. The followers of cognitive theory condemn the opinion that tends to consider that a mind does not exist since it seems does not affect an occasion. Even though thinking, deciding, stating, understanding, and so on human life facts.

The early source considered by those cognitive psychologists is free will, which is mentioned in prophet hadith as angel inspiration, temptation from the devil, and internal and external stimulus. It means that the angel chance to whisper his inspiration and a chance for the devil to whisper its temptation.

Based on the research, many cognitive psychologists believe that human behaviour and mental are influence by cognitive factors that become the centre of sense and mind. In Islam psychology, the cognitive matter is not always centred in the brain since the thinking process also involves the brain, feeling, passion, and heart. In Surah $\mathrm{Al}$ Ankabut verse 49 and Al-Hajj verse 46, cognitive has given knowledge where the centre of thinking is not in the brain but the heart. In order to understand Al Quran, people cannot only using the cognitive (brain), but it has to felt or use feeling in the heart sincerely. Understanding Al Quran can only understand by a knowledgeable person and has faith in the heart. If it is no faith, it will only become knowledge, no understanding.

\section{Intelligence in Islamic Perspective}

Brightness (in English is called intelligence and in Arabic is called al-dzaka) in linguistic meaning is understanding, speed, and perfection of something. In meaning, ability (al-qudrah) I understanding something quickly and perfect (Mujib. 2002).

Intelligence is a form of power inside the human self, influencing someone's ability in various fields. Spearman makes a formula called "general ability" that has a role in saving and bounding back information, building concepts, catching the appearance of relations and making conclusions, processing materials, and arranging new combinations from those materials.

According to Vernon (1973), there are three meanings of intelligence; first, intelligence is nature capacity that children accept from their parents through gene which determines their mental progress. Second, intelligence refers to being intelligent, quick in the act, bright in thinking and understanding, and efficient in doing mental activities. Third, intelligence is mental age or IQ or a score of intelligence test (Pellegrino and Hilton 2012).

Donald Olding Hebb firstly formulates an intelligence and B intelligence as the factor related to genotype and phenotype. Genotype factor (A) is the default factor, including the factor that is related to physic, like the brain and nerve system, which cannot be observed directly; the thing that can be observed is the behaviour (phenotype), 
which is how someone behaves, speak and think. Phenotype depends on gene interaction with the prenatal and postnatal environment. B intelligence is not static in the whole life, and it changes depending on education and experience gained by the individual. $\mathrm{C}$ intelligence results from an intelligence test, generally measuring $\mathrm{B}$ intelligence, because A intelligence is considered cannot be measured.

According to Alfred Binet (1857-1911) and Theodore Simon, intelligence consists of three components, which are the ability in directing the mind or act, the ability in changing the way of an act if it has been done, and the ability in doing selfcritic (auto criticism).

Lewis Madison Terman (1916) defines intelligence as someone able to think abstractly. H.H. Goddard (1946) defines intelligence as the ability stage of someone experience to solve problems and to anticipate upcoming problems. V.A.C Henmon states that intelligence consists of two factors; the ability to gain knowledge and knowledge that has been gained. Baldwin (1901) defines intelligence as the ability in giving a good response from the truth or fact point of view. George D. Stoddard (1941) defines intelligence as the ability to understand problems that contain difficulty, complicity, abstract, economic, that directed into one direction, having social value, and come from the source.

Walters dan Gardber (1986) defines intelligence as an ability or a bunch of abilities that enable someone to solve a problem or product due to the specific culture existence. Flynn (1987) defines intelligence as the ability to think abstractly and the readiness to learn from experience. David Wechsler, intelligence is the ability to act directly, reason, and face the environment effectively.

Generally, it can be concluded that intelligence is a mental ability that involves a rationally thinking process. Intelligence cannot be observed directly, but it must be concluded from real action that becomes the manifestation of rational thinking.

Intelligence or brightness is meant in various dimensions by experts. Donald Steiner, a psychologist, states intelligence as an ability to apply existing knowledge to solve problems. The speed can measure intelligence level in solving those problems.

Generally, intelligence also means a level of brain ability and speed in processing a kind of specified assignment or skill. The brain ability and speed is also called brain working affectivity. The following is factors that influence intelligence. First nature or heredity factor. Muhammad Saw says:

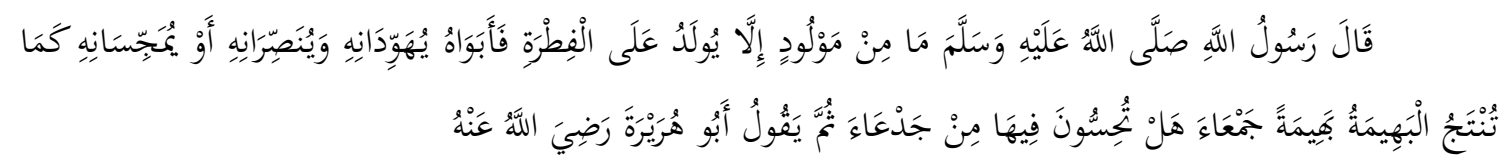

Rasulullah Shallallahu'alaihiwasallam says: "No child is born unless he is born in a state of fithrah. So then the two parents will make the child become a Jew, Christian or Magi like the cattle that give birth to cattle perfectly. Do you see any defects in him". (HR Bukhari - 1271) 
"So direct your face toward the religion, inclining to truth. [Adhere to] the fitrah of Allah upon which He has created [all] people. No change should there be in the creation of Allah . That is the correct religion, but most of the people do not know." (Q.S Ar-Ruum: 30).

Second, Environment factors. Even though some marks have been brought since born, that environment can make meaningful changes. Intelligence cannot be removed from the brain. Brain progress is influenced by the nutrition that consumed. Besides nutrition, the emotional, cognitive stimulus also has an important role. Allah states about it in Al Quran Surah Al Maidah: 3 and 88, which means: "And eat of what Allah has provided for you (which is) lawful and good. And fear Allah, in whom you are believers." (Q.S Al-Maidah: 88) and Means: "Prohibited to you are dead animals, blood, the flesh of swine, and that which has been dedicated to other than Allah, and [those animals] killed by strangling or by a violent blow or by a head-long fall or by the goring of horns, and those from which a wild animal has eaten, except what you [can] slaughter [before its death], and those which are sacrificed on stone altars, and [prohibited is] that you seek decision through divining arrows.

That is grave disobedience. This day those who disbelieve have despaired of [defeating] your religion; so fear them not, but fear Me. This day I have perfected for you your religion and completed My favour upon you and have approved for you Islam as religion. But whoever is forced by severe hunger with no inclination to sin then indeed, Allah is Forgiving and Merciful." (Q.S Al-Maidah : 3).

In the beginning, intelligence is only related to the structural ability of the mind (intellect) in catching a symptom, so intelligence is only related to cognitive aspects (almajor al-ma' rifi). Nevertheless, in the subsequent progress, it is realized that human life is about fulfilling mind structure and heart structure that needs to get a specified place to grow affective aspects (al-majal al-anfi'ali) such as emotional life, moral, spiritual, and religion. Because of that reason, the kind of intelligence in someone varies in line with ability or potential.

First, Intellectual Quotient. The intellectual quotient is the quotient that is related to the cognitive process like think, an ability to connect, and judge or considers something. Or a brightness that is related to problem-solving strategy by using logic (Zohar, 2000). It is also called rational intelligence. According to Thurstone, his multifactor theory determines 30 factors that decide intellectual brightness. Seven of them are considered the main thing for mental abilities, which are accessible using the number. Good in memory, easy to catch the relations of conversation, bright insight, easy to get conclusions from available data, quick to observe, and competent in solving the problem. 
The second, Emotional Quotient. Goleman defines emotion with specific feelings and minds, a biological and psychological situation, and a group of action tendencies (Goleman, 2000). Mayer uses the term of emotional quotient to describe a group of abilities in controlling self-emotion correctly, motivating self, knowing other people, and making relationships with other people (Tsaousis and Nikolaou 2005); (FernándezBerrocal and Extremera, 2013); (Ciarrochi, Forgas, and Mayer 2001).

The emotional quotient is the working result from the right brain, while the intellectual quotient is the working result of the left brain. According to DePorter and Hernacki, the human right brain has random performance, is unorganized, intuitive, and holistic. Meanwhile, the left brain has analytical performance, sequential, rational, and holistic. The problem that often obstructs the emotional quotient is a shame, inability to express feelings, too emotional, ambiguous feelings, frustration, no selfmotivation, hard to give empathy, and difficulty making friends.

Third, Moral Quotient. Robert Goles says that the moral quotient seems to become the third part of brain activity related to the ability to grow slowly to consider which one is right and which one is wrong by applying the human mind intellectual and emotional source. The indicator of moral intelligence is how someone knows good and bad morals. He can neutralize good morals in real life and can avoid bad morals.

The moral quotient cannot be reached by memorizing and remembering principles or rules learnt in the class. However, it needs interaction with the outside environment when a child has interacted with the surrounding. So it can be observed what kind of manner he plays, whether he has polite behaviour, full of love, giving attention, not arrogant, not egoist or selfish, and other various behaviours.

Fourth, Spiritual Quotient. A spiritual quotient is not the doctrine of the religion that asks people to be "smart" in choosing or believing one of the religions considered correct. A spiritual quotient is more than a concept related to how someone is "smart" in managing and using his spiritual life's meanings, values, and qualities. Here, the spiritual life consists of the desire to have a meaningful life, which motivates human life to find the meaning of life and hope to have a meaningful life.

Another opinion states that there is Qalbiah Intelligence (heart intelligence). The implication of qalbiah intelligence is to describe some self-ability quickly and perfectly to identify the heart and its symptoms, managing and expressing kinds of heart correctly, motivating it to build morality and ubudiyah (servitude) relation with God.

The main characteristics of qalbiah intelligence are giving intuitive ilahiyah response and prioritizing universal divinity values than temporary human values. Individual subjective reality (from worshipping experience) is placed in the 
same strength, or higher, with objective reality, reached through the religious, spiritual placement and tazkiyatun nafs (cleaning soul).

That definition can be explained in the kind of qalbiah intelligence. First, Intellectual Intelligence (intuitive) is a heart intelligence related to accepting and correcting knowledge with ilahiyah intuitive characteristics, like a prophet's revelation and inspiration or feeling for ordinary religious people.

The existence of ilahiyah intuitive becomes a differentiator with an intelligent quotient that arises up by insaniah rational mind (a mind based on human ratio). Second, the Emotional Quotient is a soul quotient related to the controlling of impulsive and aggressive desire. This quotient guides someone to act carefully, watchful, calm, patient, and tough when having calamity, ad thankful when getting enjoyment.

Fifth, Moral Quotient is a soul quotient related to the relation between humans and the universe. This quotient guides someone to act nicely so that other people will be glad without pain, jealousy, envy, revenge, and arrogance. Forth, a Soul Quotient is a soul quotient that is related to the quality of someone soul. It guides someone to be more humane, so he can reach noble values which possibly have not been reached by the human mind. Fifth, Religion Quotient is a soul quotient related to the quality of having religion and God. It is guided someone to behave correctly, which in the end it will bring deep trust, based on six belief competencies, five Islamic competencies, and multi-competence of $i$ san (sincerity).

The system approach must understand those five soul quotient models. It means each quotient is part of autonomy related to each other, like a connected chain. Conceptually, each part of those soul quotients can be understood separately, but in the natural behaviour, those quotients are mixed.

The term of soul quotient is not strange, since in Q.S Al-Hajj verse 46 stated that "So have they not travelled through the earth and have hearts by which to reason and ears by which to hear? For indeed, it is not eyes that are blinded, but blinded are the hearts which are within the breasts." (Q.S Al-Hajj: 46). That verse not only shows the soul quotient but also shows the existence of qalbiah potency, which can see something that cannot be seen by eyes because there is 'ayn al-bashirah (inner eyes). These inner eyes can penetrate the world of moral, spiritual, and religion that load the secret the magic of the universe. After someone mobilizes his all soul potential and is supported by the giving of al-rahmah al-rahimiyah (loving and compassionate) from Allah Swt, so these inner eyes will be able to find the essence.

The heart that becomes the ruler in the kingdom of the human soul is accused of controlling desire and anger. By controlling the soul, desire and anger, which at the beginning have a negative impact, turn into positive potential. According to Al- 
Ghazali, desire potential turns into will (iradah), and anger potential changes into ability (qudrah).

Qalbiah Quotient also happens when a soul can interact with the mind to reach wealth and prosperity. This kind of quotient is a combination between the faculty of zikir (remembering God) and thinking that only belong to someone that predicates as ulul albab (someone who has a mind) as stated in Q.S Ali-Imran:190-191. Lo! In the creation of the heavens and the earth and (in) the difference of night and day are tokens (of His Sovereignty) for men of understanding,

Such as remember Allah, standing, sitting, and reclining, and consider the creation of the heavens and the earth, (and say): Our Lord! Thou created not this in vain. Glory be to Thee! Preserve us from the doom of Fire (Q.S Ali-Imran: 190-191).

With its solitude, the mind does not have a negative potential because it can gain rational truth. However, suppose it is covered by its dark characteristic (zhulmaniah). In that case, it will cause anthropocentrism, like humanism, which brings atheism because the mind needs nur (light) of the soul to drive away from the growth of dark characteristics in himself.

\section{Conclusion}

Cognitive psychology is a mental faculty related to knowledge, including perception, think, identity, understand, judge and imagine. Cognition is a complex concept involving at least memory, attention, executive function, perception, language, and psychomotor function. In Islam, cognitive psychology is not always centring on the brain because the thinking process also involves the brain, feeling, desire, and heart. It can be understood from Surah Al-Ankabut verse 49, and Al Hajj verse 46, related with cognitive has given knowledge where the centre of the mind is not in the brain but the heart.

Brightness (in English is called intelligence, and in Arabic is called al-dzak'). Based on linguistic meaning, it means understanding, speed, and the perfection of something. It also has a meaning of the ability in understanding something quickly and perfectly. Factors that influenced intelligence is nature or genetic factor and environment factor. The kinds of intelligence are intellectual intelligence (intuitive), emotion, moral intelligence, spiritual intelligence, but there is essential intelligence, religion or having God intelligence.

\section{REFERENCES}

Ali, Nuraliah. (2020). 'Measuring Religious Moderation Among Muslim Students at Public Colleges in Kalimantan Facing Disruption Era'. INFERENSI: Jurnal Penelitian Sosial Keagamaan 14 (1): 1-24. https:/ / doi.org/10.18326/infsl3.v14i1.124. 
Bengtsson, Mariette. (2016). 'How to Plan and Perform a Qualitative Study Using Content Analysis'. NursingPlus Open 2 (January): 8-14. https://doi.org/10.1016/j.npls.2016.01.001.

'Book Reviews : Managerial Psychology, by Harold J. Leavitt. Chicago: The University of Chicago Press, 1958. Pp. Xi + 335 - Wallace H. Best, 1959'. 1959. 1959. https://journals.sagepub.com/doi/abs/10.1177/001316445901900437?journalC ode=epma.

Boshoff, C, and C D Pentz. (2010). 'In The Department Of Business Management At Stellenbosch University', 218.

Bostrom, Nick, and Anders Sandberg. 2009. 'Cognitive Enhancement: Methods, Ethics, Regulatory Challenges'. Science and Engineering Ethics 15 (3): 311-41. https://doi.org/10.1007/s11948-009-9142-5.

Chomsky, Noam. (1957). Syntactic Structures. The Hague: Mouton.

Ciarrochi, Joseph, Joseph P. Forgas, and John D. Mayer, eds. 2001. Emotional Intelligence in Everyday Life: A Scientific Inquiry. Philadelphia, PA: Psychology Press.

Emzir. (2010). Metodologi Penelitian Pendidikan Kuantitatif Dan Kualitatif. Jakarta: Rajawali Press.

Facebook, and Twitter. (2019). 'How Cognitive Psychology Explains the Science Behind Mental Processes'. $\quad$ Verywell 2019. https://www.verywellmind.com/cognitive-psychology-4157181.

Fernández-Berrocal, Pablo, and Natalio Extremera. 2013. 'Emotional Intelligence: A Theoretical and Empirical Review of Its First 15 Years of History', 7.

Greenfield, Thomas, and Peter Ribbins. 2015. 'Greenfield on Educational Administration: Towards a Humane Science', 295.

Herrington, Luke M. (2013). 'Globalization and Religion in Historical Perspective: A Paradoxical Relationship'. Religions $4 \quad$ (1): $145-65$. https:// doi.org/10.3390/rel4010145.

Jahanbakhsh, Forough. (2019). 'Islam, Democracy and Religious Modernism Ln Iran (1953-1997): Frûm Bàzargxn to Soroush', 329.

Lees, Robert B. (1957). Review of Review of Syntactic Structures, by Noam Chomsky. Language 33 (3): 375-408. https:/ / doi.org/10.2307/411160.

Litowitz, Douglas E. (1997). 'Postmodern Philosophy and Legal Thought', 361.

Lu, Zhong-Lin, and Barbara Anne Dosher. 2007. 'Cognitive Psychology'. Scholarpedia 2 (8): 2769. https://doi.org/10.4249/scholarpedia.2769.

Matthew, B. Miles. (1992). 'Analisis Data Kualitatif: Buku Sumber Tentang Metode Metode Baru / Matthew B. Miles, A. Michael Huberman ; Penerjemah, Tjetjep Rohendi ; Pendamping, Mulyarto | OPAC Perpustakaan Nasional RI.' 1992. https: / / opac.perpusnas.go.id/DetailOpac.aspx?id=298242.

Mohd Nasir Masroom, Siti Norlina Muhamad, and Siti A'isyah Panatik @ Abd Rahman. (2017). 'The Influence of Iman, Islam and Ihsan towards the Self WellBeing'. Jurnal Hadhari 9 (1): 63-74.

Moleong, Lexy J. (2011). Metodologi Penelitian Kualitatif. Bandung: Remaja Rosda Karya.

146 Volume 12 Nomor 2 October 2021

Submitted: 08-08-2021 Accepted: 09-09-2021 Approved: 11-09-2021 Published: 15-10-2021 
Muhaimin, AG. (2001). Islam Dalam Bingkai Budaya Lokal Potret Dari Cirebon. Jakarta: Logos.

Nehlig, Astrid. (2010). 'Is Caffeine a Cognitive Enhancer?' Journal of Alzheimer's Disease: JAD 20 Suppl 1: S85-94. https:/ / doi.org/10.3233/JAD-2010-091315.

Nielson, N. (usda, Y. Lu, and P. Colling. 1992. 'Food Consumption Trends in the Pacific Rim: Expanded Opportunities for U.S. Agriculture'. Journal of International Food and Agribusiness Marketing (USA). https://agris.fao.org/agrissearch/search.do?recordID=US9324228.

Niosi, Andrea. 2013. 'The Perceptual Process'. https://kpu.pressbooks.pub/introconsumerbehaviour/chapter/theperceptual-process/.

Pellegrino, James, and Margaret Hilton. 2012. 'Education for Life and Work: Developing Transferable Knowledge and Skills in the 21st Century', January.

Petersson, K. M., A. Reis, S. Askelöf, A. Castro-Caldas, and M. Ingvar. 2000. 'Language Processing Modulated by Literacy: A Network Analysis of Verbal Repetition in Literate and Illiterate Subjects'. Journal of Cognitive Neuroscience 12 (3): 364-82. https://doi.org/10.1162/089892900562147.

'Piaget Stages of Development: What Are They and How Are They Used?' 2018. Healthline. 27 March 2018. https:// www.healthline.com/health/piaget-stagesof-development.

Pontoh, Dr Winston. (2016). 'Staff Editorial Jurnal Accountability' 5 (2): 273.

Stangor, Dr Charles. (2014). 'The Cognitive Self: The Self-Concept', September. https://opentextbc.ca/socialpsychology/chapter/the-cognitive-self-the-selfconcept/.

Sternberg, Robert J. (2017). 'American College Journal of English Language and Literature', 147.

Sutton, Jane, and Zubin Austin. (2015). 'Qualitative Research: Data Collection, Analysis, and Management'.The Canadian Journal of Hospital Pharmacy 68 (3): 226-31. 